\title{
Korelasi Sikap Siswa dan Disiplin Siswa Terhadap Pelajaran Ipa Di Smp Muaro Jambi
}

\author{
Rio Dezaneru ${ }^{1}$, Nugroho Kurniawan ${ }^{2}$ \\ ${ }^{1,2}$ Universitas Jambi, Jambi, Indonesia
}

\begin{tabular}{l} 
Article Info \\
\hline Article history: \\
Received Jan 1, 2021 \\
Revised Jan 11, 2021 \\
Accepted Jan 25, 2021 \\
\hline
\end{tabular}

\section{Keywords:}

Disiplin Siswa

Pendidikan IPA

Sikap Siswa

\begin{abstract}
ABSTRAK
Tujuan Penelitian: (1) untuk melihat sikap siswa terhadap IPA , (2) melihat disiplin siswa terhadap IPA, dan (3) untuk melihat hubungan antara sikap dan disiplin terhadap IPA pada siswa SMP di Kabupaten Muaro Jambi.
\end{abstract}

Metodologi: penelitian dengan pendekatan kuantitatif dan dilaksanakan metode survey, Jumlah sampel penelitian sebanyak 191 siswa SMP dengan instrument yang digunakan adalah angket. Analisis data menggunakan statistik deskriptif dan inferensial.

Temuan utama: (1) sikap siswa terhadap IPA memiliki kategori baik dan sikap positif, (2) disiplin siswa terhadap IPA juga menunjukkan hasil kategori baik dengan disiplin positif, dan (3) Sedangkan korelasi antara sikap dan disiplin siswa terhadap IPA menunjukkan hubungan dengan nilai: 0,000 dan memilki derajat korelasi yang kuat dengan nilai "pearson correlation" = 0,707. Sehingga dapat disimpulkan karakter sikap siswa terhadap IPA dan disiplin siswa terhadap IPA menunjukkan kategori positif dan baik.

Keterbaruan penelitian: Sikap terhadap IPA (sains) adalah kemampuan siswa dalam menilai dan menanggapi IPA/sains. Disiplin terhadap IPA adalah kebiasaan siswa untuk berperilaku secara konsisten dan dilakukan berulang-ulang terhadap IPA, maka dari itu sikap dan karakter disiplin yang baik wajib dimiliki oleh siswa

This is an open access article under the CC BY-NC license

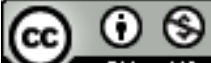

\section{Corresponding Author:}

Nugroho Kurniawan,

Pendidikan Fisika, Universitas Jambi, Jambi, Indonesia

Jl. Jambi-Ma. Bulia KM 15, Muaro Jambi, 36361, Jambi, Indonesia.

Email: kurniawan.nk97@gmail.com

\section{PENDAHULUAN}

Pendidikan adalah salah satu aspek terpenting bagi setiap individu. Karyadi (2018) "Education path can build a civilization in order to educate the nation's life" [1]. Ini dibuktikan dalam pembukaan UUD 1945, paragraf IV, yang menyatakan bahwa kehidupan intelektual bangsa adalah salah satu poin dari Negara Indonesia. Karena dalam pendidikan secara sadar akan dilakukan oleh setiap individu untuk mendapatkan pengetahuan. Pendidikan adalah dasar untuk meningkatkan dan mengembangkan kualitas setiap individu [2]. Tujuan pendidikan terkandung dalam Undang-Undang Sistem Pendidikan Nasional, yaitu untuk pengembangan siswa potensial untuk menjadi umat Allah yang setia dan takut, mulia, sehat, berpengetahuan luas, berkemampuan, kreatif, mandiri, dan warga negara demokratis dan bertanggung jawab.

Sekolah menengah pertama di Indonesia adalah salah satu jenjang pendidikan formal. Pembelajaran IPA di SMP terdiri dari materi yang terintegrasi dengan pengetahuan dan fenomena alam. Ilmu Pengetahuuan 
Alam (sains) adalah kumpulan ilmu-ilmu serumpun yang menjelaskan berbagai fenomena alam yang terjadi [3]. Setiap siswa sangat penting untuk belajar sains dengan baik. Siswa dapat diperkenalkan ke dunia sains saat mereka menjelajahi dunia alami, membaca buku dan berinteraksi dengan media digital yang terkait dengan sains, dan membuat studi pengamatan dan berhubungan dengan eksperimen sains [4]. Selain itu, sains juga mendasari kemajuan perkembangan teknologi dan sains. Menurut Rahayuni (2016) menyatakan bahwa Literasi Sains adalah hal yang sangat penting untuk dikuasai oleh masing-masing individu karena berkaitan erat dengan bagaimana seseorang dapat memahami lingkungan dan masalah lain yang dihadapi oleh masyarakat modern yang sangat bergantung pada pembangunan. sains dan teknologi, termasuk masalah social [5].

Namun muncul asumsi dari siswa yang menganggap bahwa pelajaran sains adalah pelajaran yang sulit. Menurut Astuti, dkk (2012) belajar IPA (sains) di sekolah masih merupakan pelajaran yang sulit bagi sebagian siswa Indonesia [6]. Karena itu pemerintah Indonesia memperbarui kurikulum untuk menanggapi masalah ini. Meningkatkan kualitas pendidikan sangat tergantung pada kurikulum yang diterapkan di sekolah [2]. Memperbarui kurikulum di dunia pendidikan untuk merespons tantangan zaman. Demikian juga yang ada di Indonesia, sekarang menerapkan kurikulum 2013 [7]. Kurikulum 2013 saat ini berfokus pada pendidikan karakter untuk setiap siswa. Karakter adalah objektivitas yang baik yang menunjukkan kualitas manusia, apakah diketahui manusia atau tidak, dan kebaikan ditegaskan oleh masyarakat dan agama [8]. Pathoni \& Susanti, (2016) Perubahan perilaku ini adalah perubahan karakter yang berpengetahuan (kognitif) dan keterampilan (psikomotor) dan yang terkait dengan sikap (afektif) [9].

Menurut Sudewo (2011) "karakter adalah kumpulan perilaku yang baik dari seorang anak manusia" [10]. Karakter dapat membangun profesionalisme siswa menjadi lebih baik. Profesionalisme dapat hadir dalam diri seseorang, salah satunya dengan membangun sikap yang ditumbuhkan melalui disiplin diri yang konsisten [11]. Dengan demikian karakter utama yang harus dikembangkan oleh pendidik adalah sikap siswa dan disiplin siswa. Sedangkan faktor yang berperan penting dalam sains yang dicapai oleh siswa adalah sikap sains siswa dan disiplin terhadap sains. Ini berarti bahwa sikap dan disiplin adalah karakter yang berhubungan langsung dengan setiap kegiatan sains terhadap siswa

Sikap memiliki definisi ekspresi kesenangan atau ketidaksenangan terhadap objek. Eaton \& Visser (2008) Sikap setiap individu adalah keseluruhan evaluasi (penilaian) terhadap objek dilingkungan mereka yang memiliki perhatian yang luar biasa [12]. Suryabrata (2015) Sikap tidak hanya menentukan apa yang akan dilakukan oleh seseorang tetapi juga cara yang akan memuaskan atau tidak memuaskannya [13]. Perwitasari et al (2016) aspek sikap sains menunjukkan minat dalam sains, dukungan untuk penyelidikan ilmiah, dan disiplin untuk bertindak secara bertanggung jawab terhadap, misalnya, sumber daya alam dan lingkungan [14]. "Attitudes toward science is important because attitudes can enhance the educational achievements of students and their affect performance" [15]. Karena itu, sikap sangat penting untuk dikembangkan pada setiap siswa, terutama dalam sains

Disiplin diri adalah siklus kebiasaan yang kita lakukan berulang kali dan terus menerus secara terus menerus [11]. Disiplin ini sangat berkaitan erat dengan karakter siswa. Pendidikan karakter disiplin sangat penting untuk diperhatikan dalam rangka membina karakter seseorang, khususnya siswa [16]. Disiplin terhadap sains dapat didefinisikan sebagai upaya yang baik dan konsisten dari setiap siswa untuk melakukan pembelajaran sains atau kegiatan yang terkait dengan sains berjalan secara teratur dan sistematis. Salah satu faktor yang mempengaruhi keberhasilan dalam IPA adalah disiplin yang baik. Trench \& Bucchi (2010) berpendapat bahwa pengembangan teoritis lebih lanjut diperlukan untuk mendukung penuh kemunculan komunikasi ilmu sains sebagai suatu disiplin ilmu. Oleh karena itu disiplin siswa terhadap sains sangat menentukan tingkat pengetahuan siswa [17].

Dari penjelasan di atas, dapat dilihat bahwa karakter unggul yang harus dikembangkan oleh guru kepada siswa dalam mata pelajaran IPA adalah Sikap dan Disiplin. Ini karena sikap dan disiplin terkait erat dengan karakter setiap siswa. Karena setiap siswa memiliki karakter yang berbeda, dalam penelitian ini peneliti akan menganalisis hubungan antara sikap dan disiplin siswa terhadap mata pelajaran IPA di SMP. Dalam penelitian ini akan ditampilkan hasil hubungan antara sikap dan disiplin berdasarkan indikator sikap; adopsi sikap ilmiah, dan kesenangan belajar IPA (sains); disiplin dalam mengerjakan tugas sains, dan disiplin dalam mengerjakan tugas sains.

\section{METODE PENELITIAN}

Penelitian yang digunakan adalah pendekatan kuantitatif dengan metode penelitian survei. Creswell (2016) tujuan penelitian kuantitatif adalah untuk mengidentifikasi variabel utama dalam studi penelitian [18]. Studi survei memeriksa populasi besar dan kecil dengan memilih dan menilai sampel yang dipilih dari populasi [19]. maka penelitian ini menggunakan pendekatan kuantitatif. 
Penelitian ini dilaksanakan pada Siswa/i dari 3 Sekilah Menengah Pertama (SMP) Kabuapten Muaro Jambi. Jumlah siswa yang menjadi sampel/responden penelitian adalah 191 siswa. Pengumpulan data dilakukan dengan memberikan instrumen penelitian berupa angket (kuesoner). Penelitian ini menggiunakan dua variabel, yaitu variabel sikap siswa terhadap IPA dan disiplins siswa terhadap IPA. sehingga dalam pelaksanaanya digunakan 2 jenis angket dan dengan 2 fokus penilian yang berbeda. Angket yang digunakan adalah (1) Angket sikap siswa terhadap IPA dan (2) angket disiplin siswa terhadap IPA. Dimensi sikap siswa terhadap mata pelajaran IPA diukur berdasarkan 2 indikator, yaitu: Adopsi Sikap Ilmiah, dan Kesenangan dalam belajar IPA. Sedangkan dimensi disiplin siswa terhadap IPA diukut berdasarkan 2 indikator, yaitu disiplin dalam mengerjakan tugas IPA, dan disiplin dalam mengerjakan tugas sains. Instrumen penelitian terhadap mata pelajaran sains dalam penelitian ini diukur menggunakan skala Likert. Skala skala Likert sangat baik (SB), Baik (B), Cukup (C), Buruk/tidak baik (TB), dan Sangat buruk (sangat tidak baik) (STB). Setiap item positif pada instrumen memiliki nilai: $\mathrm{SB}=5, \mathrm{~B}=4, \mathrm{C}=3, \mathrm{~TB}=2$, dan $\mathrm{STB}=1$. Data kuesioner ini diberikan kepada siswa kelas 7, kelas 8, dan kelas 9 di SMP Kab. Muaro Jambi, Provinsi Jambi.

Analisis data yang digunakan dalam penelitian ini menggunakan statistik deskripti dan inferensial, untuk statistik inferensial menggunakan uji korelasi product moment pearson

\section{HASIL DAN PEMBAHASAN}

Hasil data ini diperoleh dari angket sikap siswa dan disiplin siswa terhadap IPA (sains) yang telah dilaksanakan pada siswa kelas 7, 8 dan 9 di SMP Kab. Muaro Jambi. Pengumpulan data berasal dari 191 siswa di sekolah menengah pertama di Kab. Muaro Jambi. Hasil data diproses menggunakan statistik deskriptif dan statistik inferensial dengan berbantu perangkat lunak IBM SPSS. Hasil dari data penelitian yang ditunjukkan di bawah ini didasarkan pada indikator sikap dan disiplin sisa terhadap IPA, yaitu Adopsi sikap ilmiah, Kesenangan pelajaran sains, disiplin dalam mengerjakan tugas IPA, dan disiplin dalam mengerjakan tugas sains. Berikut ini adalah hasil dari data kuesioner berdasarkan indikator:

\subsection{Hasil}

\section{Adopsi Sikap Ilmiah}

Tabel 1 berikut adalah hasil deskripsi sikap siswa terhadap indikator Adopsi Sikap Ilmiah:

Tabel 1. Adopsi Sikap Ilmiah

\begin{tabular}{|c|c|c|c|c|c|c|c|c|c|}
\hline \multicolumn{3}{|c|}{ Klasifikasi } & \multirow{2}{*}{$\%$} & \multirow{2}{*}{$\begin{array}{l}\text { Standard } \\
\text { Deviation }\end{array}$} & \multirow{2}{*}{ Mean } & \multirow{2}{*}{ Modus } & \multirow{2}{*}{ Median } & \multirow{2}{*}{ Min } & \multirow{2}{*}{$\operatorname{Max}$} \\
\hline Interval & Perilaku sikap & Jumlah & & & & & & & \\
\hline $6,0-10,8$ & Sangat buruk & 0 & 0 & & & & & & \\
\hline $10,9-15,6$ & Buruk & 5 & 2,6 & & & & & & \\
\hline $15,7-20,4$ & Cukup & 62 & 32,5 & 0,68 & 3,7 & 4,0 & 4,0 & 2 & 5 \\
\hline $20,5-25,2$ & Baik & 104 & 54,5 & & & & & & \\
\hline $25,3-30,0$ & Sangat Baik & 20 & 10,5 & & & & & & \\
\hline Total & & 191 & 100 & & & & & & \\
\hline
\end{tabular}

Dari tabel 1 sikap siswa terhadap IPA/sains berdasarkan indikator adopsi sikap ilmiah menunjukkan hasil kategori sikap berikut: kategori sikap siswa sangat buruk yaitu 0\%, siswa dengan kategori buruk sebanyak 2,6\% (5 dari 191 siswa), siswa dengan kategori cukup sebanyak 32,5\% (62 dari 191 siswa), siswa dengan kategori baik sebanyak 54,5\% (104 dari 191 siswa), dan siswa dengan sikap sangat baik sebanyak 10,5\% (20 dari 191 siswa). berdasarkan hasil tersebut menunjukkan hasil sikap positif dengan dominan siswa berada pada kategori sikap baik.

\section{Kesenangan Dalam Belajar IPA}

Berikut pada tabel 2 adalah hasil deskripsi sikap siswa terhadap IPA berdasarkan indikator kesenangan belajar IPA (sains). 
Tabel 2. Kesenangan dalam Belajar IPA (Sains)

\begin{tabular}{clcccccccc}
\hline & Klasifikasi & & $\%$ & $\begin{array}{l}\text { Standard } \\
\text { Deviation }\end{array}$ & Mean & Modus & Median & Min & Max \\
\hline Interval & Perilaku sikap & Jumlah & & & & & & & \\
\hline $6,0-10,8$ & Sangat buruk & 0 & 0 & & & & & \\
$10,9-15,6$ & Buruk & 12 & 6,3 & & & & \\
$15,7-20,4$ & Cukup & 56 & 29,3 & 0,81 & 3,75 & 4,0 & 4,0 & 2 \\
$20,5-25,2$ & Baik & 91 & 47,6 & & & & & \\
$25,3-30,0$ & Sangat Baik & 32 & 16,8 & & & & & \\
\hline Total & 191 & 100 & & & & \\
\hline
\end{tabular}

Berdasarkan tabel 2 adalah hasil evaluasi sikap siswa terhadap IPA berdasarkan indikator; kesenangan dalam pembelajaran IPA (sains), menunjukkan menujukkan hasil berikut: kategori sikap siswa sangat buruk sebanyak 0\% (0 dari 191 siswa), kategori buruk sebanyak 6,3\% (12 dari 191 siswa), kategori sikap cukup sebanyak 29,3\% (56 dari 191 siswa), kategori baik sebanyak 47,6,\% (91 dari 191 siswa) dan kategori sangat baik sebanyak 6,8\% (32 dari 191 siswa). Maka, dari hasil tersebut disimpulkan sikap siswa terhadap IPA pada indikator kesenangan dalam belajar IPA (Sains) tergolong pada sikap positif dengan sikap dominan berada paa kategori $n$ baik.

\section{Disiplin Dalam Mengerjakan Tugas Sains}

Berikut ini adalah hasil analisis data deskriptif disiplin siswa terhadap sains berdasarkan indikator disiplin dalam mengerjakan tugas IPA, dapat dilihat dari tabel 3 berikut ini:

Tabel 3. Disiplin Mengerjakan Tugas Sains

\begin{tabular}{|c|c|c|c|c|c|c|c|c|c|}
\hline \multicolumn{3}{|c|}{ Klasifikasi } & \multirow{2}{*}{$\%$} & \multirow{2}{*}{$\begin{array}{l}\text { Standard } \\
\text { Deviation }\end{array}$} & \multirow{2}{*}{ Mean } & \multirow{2}{*}{ Modus } & \multirow{2}{*}{ Median } & \multirow{2}{*}{ Min } & \multirow{2}{*}{ Max } \\
\hline Interval & Perilaku sikap & Jumlah & & & & & & & \\
\hline $7,0-12,6$ & Sangat buruk & 6 & 3,1 & & & & & & \\
\hline $12,7-18,2$ & Buruk & 21 & 11,0 & & & & & & \\
\hline $18,3-23,8$ & Cukup & 51 & 26,7 & 1,04 & 3,6 & 4,0 & 4,0 & 1 & 5 \\
\hline $23,9-29,4$ & Baik & 71 & 37,2 & & & & & & \\
\hline $29,5-35,0$ & Sangat Baik & 42 & 22,0 & & & & & & \\
\hline Total & & 191 & 100 & & & & & & \\
\hline
\end{tabular}

Tabel 3 Adalah hasil disiplin siswa terhadap IPA berdasarkan indikator disiplin dalam mengerjakan tugas IPA yang menunjukkan hasil berikuti ini: kategori disipli siswa sangat buruk sebanyak 3,1\% (6 dari 191 siswa), siswa dengan kategori buruk sebanyak sebagai 11\% (21 dari 191 siswa), kategori disiplin cukup sebanyak 26,7\% (51 dari 191 siswa), kategori siswa dengan disiplin baik sebanyak 37,2\% (71 dari 191 siswa) dan siswa dengan disiplin sangat baik sebanyak 22\% (42 dari 191 siswa). Berdasarkan hasil tersebut nilai kategori paling dominan berada pada kategori baik, maka disimpulkan tergolong disiplin positif.

\section{Disiplin Belajar Sains Di Rumah}

Berikut ini adalah hasil analisis disiplin siswa terhadap indikator disiplin belajar sains di rumah.

Tabel 4. Disiplin Mengerjakan Tugas Sains

\begin{tabular}{|c|c|c|c|c|c|c|c|c|c|}
\hline \multicolumn{3}{|c|}{ Klasifikasi } & \multirow{2}{*}{$\%$} & \multirow{2}{*}{$\begin{array}{l}\text { Standard } \\
\text { Deviation }\end{array}$} & \multirow{2}{*}{ Mean } & \multirow{2}{*}{ Modus } & \multirow{2}{*}{ Median } & \multirow{2}{*}{ Min } & \multirow{2}{*}{ Max } \\
\hline Interval & Perilaku sikap & Jumlah & & & & & & & \\
\hline $6,0-10,8$ & Sangat buruk & 4 & 2,1 & & & & & & \\
\hline $10,9-15,6$ & Buruk & 24 & 12,6 & & & & & & \\
\hline $15,7-20,4$ & Cukup & 56 & 29,3 & 0,99 & 3,6 & 4,0 & 4,0 & 1 & 5 \\
\hline $20,5-25,2$ & Baik & 74 & 38,7 & & & & & & \\
\hline $25,3-30,0$ & Sangat Baik & 33 & 17,3 & & & & & & \\
\hline Total & & 191 & 100 & & & & & & \\
\hline
\end{tabular}

Berdasarkan hasil analisis data tabel 4. dapat dijelaskan hasil disiplin siswa terhadap IPA berdasarkan indikator disiplin IPA di rumah ialah sebagai berikut: kategori disiplin siswa sangat buruk sebanyak 2,1\% (4 dari 191 siswa), siswa dengan kategori buruk sebanyak 12,6\% (24 dari 191 siswa), siswa dengan kategori cukup sebanyak 29,3\% (56 dari 191 siswa), siswa dengan kategori baik sebanyak 38,7\% (74 
dari 191 siswa) dan siswa dengan sikap sangat baik sebanyak 17,3\% (33 dari 191 siswa). Maka dapat disimpulkan nilai kategori disiplin siswa berada pada kategori baik dan tergolong disiplin positif.

\section{Korelasi Antara Sikap Dan Disiplin terhadap Sains}

Analisis Korelasi antara sikap siswa dan disiplin siswa terhadap IPA (sains) dianalisis dengan statistik inferensial. Proses analisis statistik inferensial menggunakan software brbantu IBM SPSS Statistics dengan menggunakan "uji korelasi pearson". Berikut tabel 5 adalah hasil korelasi sikap siswa dan disiplin siswa terhadap IPA.

Tabel 5. Nilai Korelasi Sikap dan Disiplin Terhadap IPA

\begin{tabular}{lccc}
\hline & & Sikap & Disiplin \\
\hline Sikap terhadap & Pearson Correlation & 1 & $707^{* * *}$ \\
IPA & Sig. (2-tailed) & &, 000 \\
& $\mathrm{~N}$ & 191 & 191 \\
Disiplin & Pearson Correlation &, $707^{* *}$ & 1 \\
terhadap IPA & Sig. (2-tailed) &, 000 & \\
& $\mathrm{~N}$ & 191 & 191 \\
\hline
\end{tabular}

Berdasarkan hasil data korelasi, dapat dilihat pada kelas 5 memiliki nilai sig yaitu 0,000. Dengan ketentuan uji korelasi dapat dikatakan memiliki hubungan jika sig lebih kecil dari $(<) 0,05$. Jadi dengan hasil tabel 5. antara variabel sikap dan disiplin terhadap IPA memiliki hubungan/korelasi.

\subsection{Pembahasan}

\section{Sikap siswa terhadap IPA}

Sikap terhadap IPA merupakan variabel karakter yang sudah melekat pada setiap individu. Hanya saja bagaimana penilaian individu terhadap objek tertentu yang akan mempengaruhi sikap negatif dan sikap positif mereka. Termasuk dalam hal penilaian terhadap IPA akan mempengaruhi bagaimana sikap siswa terhadap IPA. Sikap siswa terhadap objek IPA di sekolah dapat ditunjukkan dengan reaksi mereka pada mata pelajaran IPA [20]. Era terbaru dalam pendidikan ini sudah diyakini bahwa faktor pendidikan bukan saja memfokuskan pada aspek kognitif, melainkan juga pada segi keterampilan dan karakter/perilaku (afektif) siswa. Oleh karena itu penilaian sikap terhadap IPA dapat juga diasumsikan saran untuk mengembangkan dalam menilai karakter siswa, sehingga dapat dikategorikan penting. Investigasi sikap siswa terhadap pelajaran IPA telah menjadi suatu bagian terpenting dan subtantif pada subjek kerja atau komunitas penelitian yang berkaitan pada bidang penidikan IPA (sains) dalam kurun waktu 30-40 tahun ini [21].

Kembali pada hasil penelitian sikap siswa terhadap IPA pada penelitian ini menunjukka suatu hasil yang positif. Hal tersebut dibuktikan dari hasil dimensi sikap pada masing-masing indikator sikap siswa terhadap IPA (tabel 1, dan tabel 2) yang menunjukkan hasil baik. hasil penelitian menunjukkan sebagai berikut; (1) adopsi sikap ilmiah menunjukkan siswa dominan pada kategori perilaku sikap baik dengan nilai 54,5\% (104 dari 191 siswa), dan (2) kesenangan dalam belajar IPA menunjukkan siswa dominan pada kategori baik dengan nilai 47,6\% (91 dari 191 siswa). Berdasarkan dari masing-masing indikator sikap siswa terhadap IPA tersebut menunjukkan bahwa siswa mayortas memiliki kateogori sikap yang baik. sehingga dapat disimpulkan sikap terhadap IPA dalam penelitian ini menunjukkan sikap positif.

Selain dari hasil tersebut didukung juga temuan-temuan penelitian yang mendukung sikap positif siswa terhadap IPA. Penemuan-penemuan tersebut adalah siswa memiliki ketertarikan terhadap fenomena alam yang dikaji secara ilmiah, siswa memilliki kesenangan dalam hal kegiatan belajar IPA di kelas, siswa juga berpendapat bahwa menjadi ilmuwan atau mendalami ilmu sains adalah suatu hal yang menarik. Pada faktanya adalah siswa menganggap IPA bernilai positif terhadap dirinya. Memiliki sikap positif terhadap sains memengaruhi kemampuan yang terkait dengan sains [22]. Hasil tersebut menunjukkan hal baik untuk siswa dalam pembelajaran IPA.

\section{Disiplin siswa terhadap IPA}

Disiplin merupakan perilaku yang melekat pada individu, dan krusial karena berkaitan langsung dengan perilaku/karakter pada setiap individu [23]. Karena disiplin merupakan perilaku yang cenderung menjadi kebiasaan dan konsisten untuk dilakukan, maka disiplin yang positif adalah melakukan kebiasaan yang positif secara terus menerus. Maka, perilaku kedisplinan yang positif terhadap IPA ialah konsisten melaksanakan suatu kebiasaan yang baik dalam objek Pendidikan IPA. Disiplin juga menjadi bagian penting dalam implementasi pendidikan, termasuk pada pembelajaran IPA. Menurut Sumantri (2010) salah satu 
faktor intern yang mempegaruhi prestasi belajar adalah disiplin [24]. Maka sudah seharusnya penerapan disiplin dalam aspek belajar IPA semakin digalakkan, agar tercapai tujuan positif dalam aspek pembelajaran.

Berdasarkan hasil disiplin siswa terhadap IPA (tabel 3, dan tabel 4) pada penelitian ini menunjukkan hasil yang positif. Hasil penelitian disiplin siswa terhadap IPA pada setiap indikator, yakni: (1) disiplin mengerjakan tugas IPA siswa dominan menunjukkan disiplin berkategori baik dengan nilai 37,2\% (71 dari 191Siswa), dan (3) disiplin belajar IPA di rumah menunjukkan kategori disiplin baik dengan nilai 38,7\% (74 dari 191 siswa). Sehingga dari hasil ketiga indikator disiplin tersebut dapat disimpulkan bahwa disiplin siswa terhadap IPA tergolong dalam kategori baik dengan disiplin positif. Tentunya hal ini sangat memberikan dampak postifi pada siswa.

Selain itu hasil positif siswa pada disiplin terhadap objek IPA juga didukung pada temuan-temuan penelitian ini. Temuan penelitian ini merupakan konklusi dari setiap indikator disiplin siswa terhadap IPA. Temuan penelitian dalam penelitian ini antara lain; siswa rajin dan aktif dalam proses pembelajaran IPA di kelas, siswa bertanggung jawab dan mandiri dalam mengerjakan tugas-tugas IPA yang didapat di sekolah, dan siswa menganggap belajar di rumah adalah suatu kebutuhan. Maka dari hasil statistik dan temuan obserbasi penelitian dipastikan bahwa disiplin siswa di lingkup objek IPA tergolong dalam disiplin postifi dengan kategori dominan yang baik. dengan demikian siswa memiliki kebiasaan perilaku konsisten yang positif terhadap pelaksaan pembelajaran kegiatan IPA di sekolah ataupun di luar sekolah. Tentunya penerapan disiplin terhadap objek pembelajaran (khususnya IPA) sudah seyogyakan diterapkan sebaik mungkin. Menurut Wirantasa (2017) Karena dengan disiplin, siswa akan didisiplinkan untuk mencapai apa yang diinginkan dan diinginkan siswa [25].

\section{Korelasi Sikap dan Disiplin Siswa Terhadap IPA}

Sikap dan disiplin adalah karakter yang harus dimiliki oleh setiap siswa dengan baik. Sikap positif siswa terhadap IPA (sains) akan melihat objek sains sebagai hal yang menarik dan menanggapi dan melakukan hal-hal yang berkaitan dengan IPA secara baik (positif). Selaras dengan sikap positif, disiplin yang baik adalah kedisiplinan yang positif. Disiplin postif terhadap IPA(sains) merupakan perilaku dan kebiasaan siswa yang secara konsisten dan cenderung menjadi karakter tetap pada pelaksaan kegiatan IPA. sikap positif dengan disiplin postif terhadap IPA dianggap menjadi faktor ketercapaiannya efektifitas dan keberhasilan belajar IPA. Sehingga dengan dasar itu, sikap dan disiplin dianggap memiliki korelasi dan keterkaitan dalam pembelajaran IPA. yang saling sinergi dan selaras. Sejalan dengan hal itu dalam penelitian ini berfokus untuk menganalisis bagaiamana hubungan antara sikap siswa dan disiplin siswa terhadap objek IPA.

Berdasarkan tabel 5. uji coba korelasi antara sikap dan disiplin pada siswa SMP di Kabupaten Muaro Jambi menunjukkan nilai sig 0,000. Dengan ketentuan uji korelasi, jika nilai sig <0,05 maka antara variabel disiplin siswa dan sikap siswa terhadap memiliki hubungan dan korelasi yang saling berkaitan. Sedangkan dalam tabel 5. juga menunjukkan tingkat atau derajat korelasi. Derajat korelasi ini dimaknasi sebagai tingkatan kekuatan dan keeratan hubungan antara kedua variabel disiplin dan sikap terhadap IPA. Nilai korelasi yang ditunjukkan dalam "Pearson Correlation" adalah 0,707. Nilai derajat korelasi $=0,707$ menunjukkan bahwa tingkatan hubungan antara sikap siswa dan disiplin memiliki hubungan signifikan yang "skuat".

Selain itu, Hasil nilai sig 0,000 tersebut menunjukkan bahwa antara variabel sikap dan disiplin memiliki korelasi positif. Hubungan positif dapat diasrtikan sebagai kenaikan diantara kedua variabel berjalan secara selaras/beriringan. Atau dapat disimpulkan bahwa ketika nilai atau sikap siswa terhadap IPA meningkat, maka akan diikuti juga peningkatan secara searah oleh nilai atau kedisiplinan siswa terhadap IPA. sedangkan derajat korelasi yang menunjukkan signifikansi secara "kuat" mengartikan bahwa peningkatan nilai dan perilaku disiplin dan sikap siswa memiliki nilai dan keeratan korelasi yang kuat. Dampak positif nya adalah siswa yang memiliki sikap positif yang semakin baik dalam pembelajaran IPA maka juga akan diikuti juga tingkat disiplin siswa yang semakin baik juga terhadap IPA Jadi dalam penelitian ini disimpulkan bahwa antara variabel disiplin dan variabel sikap terhadap mata pelajaran IPA memiliki implikasi positif bagi mata pelajaran IPA. Ini berarti bahwa jika setiap siswa memiliki disiplin yang baik terhadap sains, itu akan mempengaruhi sikap siswa terhadap IPA menjadi sikap positif, atau perilaku menerima dengan baik pada mata pelajaran IPA (sains) untuk setiap siswa. Didukung Rijal \& Bachtiar (2015) menyatakan bahwa sikap positif terhadap pembelajaran akan memberikan dampak yang terhadap hasil belajar siswa [26]. Selaras dengan hal itu, menurut Aslianda, Israwati, Nurhaidah (2017) menyatakan bahwa ada pengaruh positif dari disiplin pada hasil belajar [27]. 


\section{KESIMPULAN}

Berdasarkan hasil penelitian, sikap siswa terhadap IPA kategori baik dengan, serta disiplin siswa terhadap IPA menunjukkan kategori disiplin baik dengan kategori disiplin positif. Sedangkan korelasi antara sikap siswa terhadap IPA siswa dengan disiplin terhadap IPA di SMP Kab. Muaro Jambi menunjukkan adanya hubungan dengan dibuktikan nilai sig 0,000, nilai korelasi ini juga menunjukkan hubungan/korelasi positif antara kedua variabel sikap siswa dan disiplin terhadap IPA. Selain itu derajat korelasi ini menunjukkan kategori kuat ditunjukkan nilai "Pearson Correlation" = 0,707. Maka dapat disimpulkan sikap siswa dan disiplin siswa terhadap IPA menunjukkan hasil baik dan positif.

\section{UCAPAN TERIMA KASIH}

Peneliti mengucapkan terima kasih kepada seluruh siswa tingkat SMP Kab. Muaro Jambi yang telah menjadi responden penelitian dan membantu dalam terlaksananya penelitian ini. Selanjutyna kepada Departemen Program Studi Pendidikan Fisika Universitas Jambi atas partisipasi dan kerjasama.

\section{REFERENSI}

[1] Karyadi, et al, "Correlation Analysis between External Factors and Student's Physics Learning Achievement," Scientiae Educatia : Jurnal Pendidikan Sains, pp. 42-54, 2018

[2] Maulana., Jufrida., dan H. Pathoni, "Upaya Meningkatkan Pemahaman Konsep Siswa Menggunakan Discovery Based Learning Dengan Bantuan LKS Digital Materi Fluida Dinamik Kelas XI SMAN 11 Kota Jambi," GRAVITY. vol. 4 , no. 2, pp. 67-81, 2018

[3] A. Doyan., M. Taufik, dan R. Anjani, "Pengaruh Pendekatan Multi Representasi Terhadap Hasil Belajar Fisika Ditinjau dari Motvasi Belajar Peserta Didik," Jurnal Penelitian Pendidikan IPA (JPPIPA), vol. 4 , no. 1, pp. 35-45, 2018

[4] J. M. Alexander., K. E. Johnson., dan K. Kelley, "Longitudinal Analysis of the Relations Between Opportunities to Learn About Science and the Development of Interests Related to Science," Science Education. 2012

[5] G. Rahayuni, "Hubungan Keterampilan Berpikir Kritis Dan Literasi Sains Pada Pembelajaran IPA Terpadu Dengan Model PBM dan STM," Jurnal Penelitian dan Pembelajaran IPA, vol. 2, no. 2, pp. 131-146, 2016.

[6] R. Astuti., S. Widha., dan S. Suciati, "Pembelajaran IPA Dengan Pendekatan Keterampilan Proses Sains Menggunakan Metode Eksperimen Bebas Termodifikasi Dan Eksperimen Terbimbing Ditinjau Dari Sikap Ilmiah Dan Disiplin Belajar Siswa,” Jurnal Inkuiri, vol. 1, no. 1, pp. 51-59, 2012.

[7] R. Ningsih., S. Endang., dan S. Bambang, "Pengaruh Penggunaan Perangkat Pembelajaran Ipa Terpadu Tipe Connected Terhadap Kompetensi Pengetahuan dan Keterampilan Siswa SMP Negeri 2 Kelumpang Tengah," Pendidikan Sains Pascasarjana Universitas Negeri Surabaya, vol. 6, no. 2, 2017.

[8] T. Lickona, "Character Matters (Persoalan Karakter) : Bagaimana Membantu Anak Mengembangkan Penilaian Yang Baik, Integritas, dan Kebajikan Penting Lainnya," Jakarta : Bumi Aksara, 2012

[9] H. Pathoni., \& N. Susanti, "Pembelajaran kolaboratif berbasis lesson study menggunakan modul guided inquiry di MTS Laboratorium Kota Jambi,” Jurnal Pendidikan Fisika dan Teknologi, vol 2. no 4, pp. 142-146, 2016.

[10] Sudewo, "Best Practice Character Building, Menuju Indonesia Lebih Baik, " Jakarta Selatan: Republika, 2011.

[11] A. M. Saleh, “Membangun Karakter Dengan Hati Nurani: Pendidikan Karakter Untuk Generasi Bangsa," Jakarta: Erlangga, 2012.

[12] A. A. Eaton., dan P. S. Visser, "Attitude Importance: Understanding the Causes and Consequences of Passionately Held Views," Social and Personality Psychology Compass, 1719-1736.

[13] S Suryabrata, "Psikologi Pendidikan," Jakarta: PT Raja Grafindo Persada, 2015.

[14] T. Perwitasari., Sudarmin, dan L. Suharto, "Peningkatan Literasi Sains Melalui Pembelajaran Energi Dan Perubahannnya Bermuatan Etnosains Pada Pengasapan Ikan,” Jurnal Penelitian Pendidikan IPA, vol. 1, no. 2 , 62-70, 2016.

[15] M. J. Liaghatdar., A. Soltani., dan A. Abedi, "A Validity Study of Attitudes toward Science Scale among Iranian Secondary School Students," International Education Studied, 2011.

[16] W. Wuryandani., B. Maftuh., dan D. Budimansyah, "Pendidikan Karakter Disiplin Di Sekolah Dasar," Cakrawala Pendidikan, vol. 33, no. 2, pp. 286-295, 2014.

[17] B. Trench., dan M. Bucchi, "Science Communication, An Emerging Discipline," Journal of Science Communication, vol. 9, no 3, 2010.

[18] J. W. Creswell, "Research Design, Qualitative, Quantitative, and Mixed Methods Approaches, Fourth Edition," Yogyakarta: Pustaka Belajar, 2012.

[19] F. N. Kerlinger, “Asas-Asas Penelitian Behavioral,” Yogyakarta: Gadjah Mada University Press, 2014. 
[20] D. A. Kurniawan., A. Astalini, dan N. Kurniawan, "Analisis Sikap Siswa SMP terhadap Mata Pelajaran IPA," Lentera Pendidikan : Jurnal Ilmu Tarbiyah dan Keguruan, vol. 22, no. 2, pp. 323- 334, 2019.

[21] J. Osborne., S. Simon. \& S. Collins, "Attitudes towards science: A review of the literature and its implications," International Journal of Science Education, vol. 25, no. 9, pp. 1049-1079, DOI: 10.1080/0950069032000032199

[22] E. Usta., dan C. Akkanat, "Investigating Scientific Creativity Level of Seventh Grade Students," Social and Behavioral Sciences, pp. 1408 - 1415, 2015.

[23] D. A. Kurniawan., A. Astalini, N. Kurniawan., dan H. Pathoni, "Analisis Korelasi Sikap dan Disiplin Siswa Terhadap IPA pada Siswa SMP Provinsi Jambi," Jurnal Pendidikan Fisika dan Keilmuan (JPFK), vol. 5, no. 2, pp. 59-75. 2019.

[24] B. Sumantri, "Pengaruh Disiplin Belajar Terhadap Prestasi Belajar Siswa Kelas XI SMK PGRI 4 Ngawi Tahun Pelajaran 2009/2010,” Jurnal Media Prestasi, vol. 6, no. 3, pp. 117-131, 2010.

[25] U. Wirantasa, "Pengaruh Kedisiplinan Siswa Terhadap Prestasi Belajar Matematika," Jurnal Formatif, vol. 7, No. 1, pp. 83-95, 2017.

[26] S. Rijal., dan S. Bachtiar, "Hubungan antara Sikap, Kemandirian Belajar, dan Gaya Belajar dengan Hasil Belajar Kognitif Siswa," Jurnal Bioedukatika, vol. 3, no. 2, pp. 15-20, 2015.

[27] Z. Aslianda., Israwati, dan Nurhaidah, "Hubungan Disiplin Belajar Terhadap Hasil Belajar Siswa Kelas IV Sekolah Dasar Negeri 18 Banda Aceh,” Jurnal Ilmiah Pendidikan Guru Sekolah Dasar, vol. 2, no. 1, pp. 236-243, 2017. 